\title{
Influence of Copper and Arsenic on Gold Recovery in the Yalea Deposit, Western Mali
}

\author{
Fodé Tounkara',2*, Jianguo Chen1, Mory Sidibe², Oumar Soumare ${ }^{3}$ \\ ${ }^{1}$ State Key Laboratory of Geological Processes and Mineral Resources, China University of Geosciences (Wuhan), Wuhan, China \\ ${ }^{2}$ Université de Ségou, Ségou-size à Sebougou, BP: 24, Ségou, Mali \\ ${ }^{3}$ Ecole Nationale d’Ingénieurs Abderhamane Baba Touré, Bamako, Mali \\ Email: ^fode1986@yahoo.fr
}

How to cite this paper: Tounkara, F., Chen, J.G., Sidibe, M. and Soumare, O. (2021) Influence of Copper and Arsenic on Gold Recovery in the Yalea Deposit, Western Mali. Open Journal of Geology, 11, 142-154.

https://doi.org/10.4236/ojg.2021.114008

Received: February 26, 2021

Accepted: April 27, 2021

Published: April 30, 2021

Copyright $\odot 2021$ by author(s) and Scientific Research Publishing Inc. This work is licensed under the Creative Commons Attribution-NonCommercial International License (CC BY-NC 4.0). http://creativecommons.org/licenses/by-nc/4.0/ (c) (i) (5) Open Access

\begin{abstract}
Gold recovery process is well known. The following paper presents the problematic related to the influence of Copper and Arsenic on the recovery of gold in the Yalea deposit. Multielement tests ( $\mathrm{Au}, \mathrm{Cu}, \mathrm{As})$ carried out on 37 blocks made it possible to understand that there is a correlation between these elements. This correlation has been observed since the analysis of block models (the block model for Copper, block model for Arsenic and the block model for gold. These models have shown that the Yalea deposit areas with a high gold content correspond to areas of high copper content and arsenic. Those who made it clear that copper and Arsenic are tracing elements of Gold in the Yalea deposit. In this paper, the mineralurgical tests carried out on 28 blocks revealed that the copper and the arsenic content in the ore penalize the recovery of Gold (146 ppm for copper and $4710 \mathrm{ppm}$ for Arsenic). The Yalea deposit was emplaced by several hydrothermal phases that reactivated the structures. These phases are responsible for the establishment of large quantities of copper sulphides. Copper and Arsenic are elements that have a considerable influence on the gold recovery in the Yalea deposit.
\end{abstract}

\section{Keywords}

Gold Recovery, Yalea Deposit, Mineralurgical Tests, Tracing Elements

\section{Introduction}

In Mali, gold export has substantially increased since the 1990s [1]. Copper and Arsenic show serious problems in gold ore processing if their content reaches a threshold.

Gold ore processing and all the technical processes used to extract gold from 
this ore, its recovery rarely reaches $100 \%$.

However, all primary gold deposit in West Africa can be classified as orogenic type gold deposits [2]. West Africa suffers from artisanal and small-scale mining formalization problem as other mineral rich countries in the region [3]. According to the available information [4] [5] [6], there is limited research on gold resource in Mali. The purpose is to understand the gold recovery process. Recovery is one of the important parameters in mining; its weakness can lead to the cessation of exploitation. Despite its high gold content, Yalea and Syama ore is a refractory gold ore due to its mineralogical composition, which contains elements such as $\mathrm{Cu}$ and As [7].

\section{Geological Setting}

\subsection{Regional Geology}

\subsubsection{The West African Craton}

The West African craton identified by Kennedy in 1964, is the part of West Africa consisting of Archaean and Proterozoic lower stable formations around 1600 - $1500 \mathrm{Ma}$ and that would result from a continental collision.

The craton is partially masked by transgressive Proterozoic cover Upper $\mathrm{Pa}$ laeozoic basin of Taoudeni, Tindouf, Bove and Volta (Figure 1).

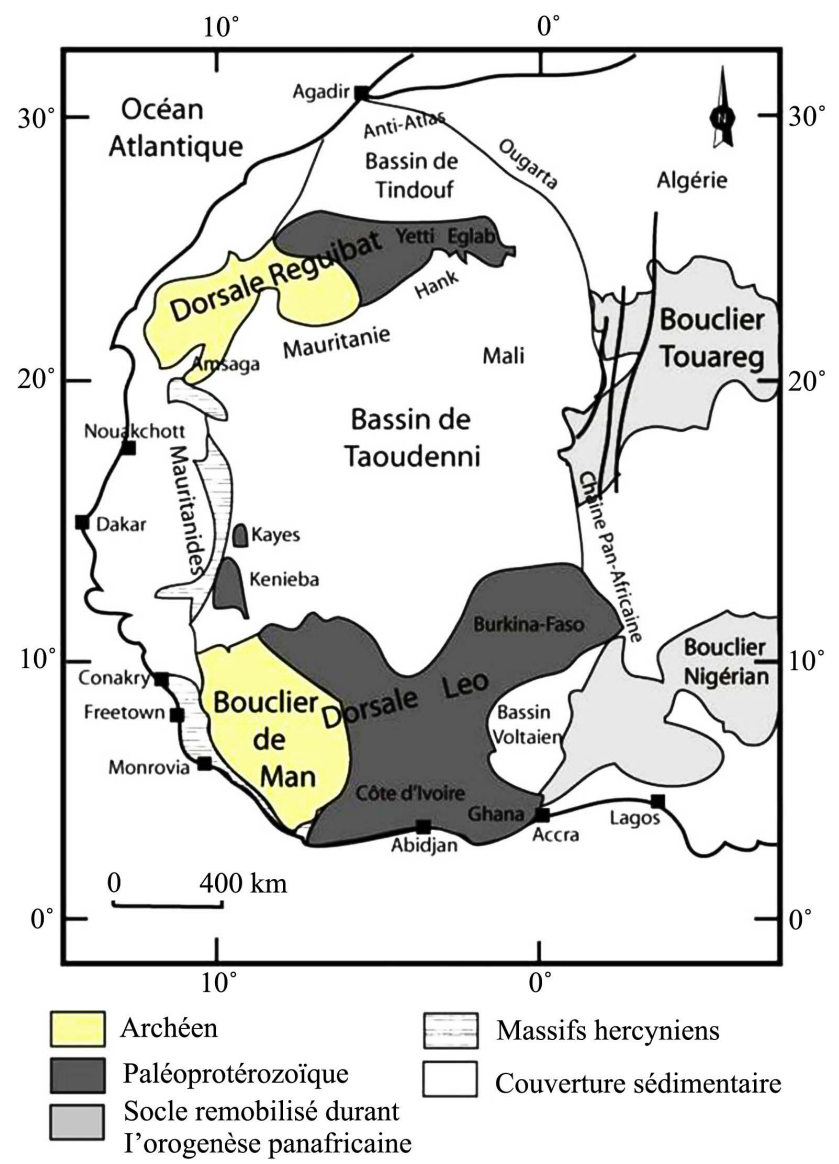

Figure 1. Main units of the West African craton. 
It is bordered to the west by the poly-orogenic belts of Mauritanides and Rockelides (Pan-African and Hercynian), in the North by the domain of Anti-Atlas; in the East by the Pharusian and Dahomeian pan-African belts.

It comprises three large structural units within the North the ridge of Reguibat, in the South the dorsal of Leo or Man and in its middle part the window of Kayes and the buttonholes of Kedougou-Kéniéba.

\subsubsection{Structural Setting}

The study area is located in The Kedougou-Kéniéba window. The context regional shows the following characteristics:

- The Senegalo-Malian accident [8], which is in parallelto Faleme River;

- The Main Transcurrent Zone called MTZ.

In addition to these two major structures, second order structures exist. The structures N000 to N020 and N070 second order faults control the mineralization at level of their intersections; especially in the areas of change of direction of the Senegalese-Malian structure. Field observations have shown that the sequences are reversed especially where the Senegalese-Malian structure changes direction.

The Senegalo-Malian structure is interpreted as a reverse slope inclined towards the west of which the east part constituting the wall forms a vast fold (Sadiola is on a large synclinal, Loulo and Segala are on a wide anticline).

The large deposits currently known are located east of this structure and are associated with second order inverse faults [9].

\section{Mineralogical Analysis}

The main mineralization phase occurs late in fluid history, located in the narrow, ductile and fragile shears that deform the weathering material early of distinct form [10]. Yalea gold is bound to several sulphide phases (Pyrites and Arsenopyrites) which are the dominant phases and several phases of copper-bearing sulphides (Chalcopyrite and Tennantite); in the gangue phase, the accessory minerals are: Apatite Rutile andIlmenite and Leucite (Table 1 and Table 2).

Table 1. Mineralogy of the ore.

\begin{tabular}{ccccc}
\hline $\begin{array}{c}\text { Hydrothermal } \\
\text { alteration } \\
\text { minerals }\end{array}$ & $\begin{array}{c}\text { Supergene } \\
\text { alteration } \\
\text { minerals }\end{array}$ & $\begin{array}{c}\text { Minerals } \\
\text { in the } \\
\text { veins }\end{array}$ & Gangue & Sulfides/Mat \\
\hline $\begin{array}{c}\text { Albite, Ankerite, } \\
\text { Quartz, Hematite, } \\
\text { Sericite, Chlorite }\end{array}$ & $\begin{array}{c}\text { covellite, } \\
\text { chalcocite }\end{array}$ & $\begin{array}{c}\text { Ankerite, } \\
\text { Quartz }\end{array}$ & $\begin{array}{c}\text { Ilmenite, } \\
\text { leucite }\end{array}$ & $\begin{array}{c}\text { Pyrite, Arsenopyrite, jamesonite, } \\
\text { pyrrhotite, Arsenopyrite, Galena, } \\
\text { scheelite, tennantite, Chalcopyrite, Gold }\end{array}$ \\
\hline
\end{tabular}

Table 2. Mineral paragenesis.

\begin{tabular}{ccc}
\hline dominant sulphides & mineral paragenesis & \\
\hline & minerals & Elements \\
\cline { 2 - 3 } Pyrite and & Chalcopyrite + Tennantite + Scheelite + \\
Arsenopyrite & Pyrrhotite + Native Gold + & Fe-As-Cu-W-Au-Ag-Pb \\
& Galena + Jamesonite & \\
\hline
\end{tabular}


Yalea is a deposit rich in arsenic (30\% to 35\% Arsenopyrite) with a combination of typical Fe-As-Cu-W-Au-Ag-Pb metal.

\section{Methodology of Research}

In this paper, the first work is to collect samples analysis result. The next step is to make mineralurgical tests and make a statistical data processing. The following paper presents the problematic related to the influence of Copper and Arsenic on the recovery of gold in the Yalea deposit. Multielement tests $(\mathrm{Au}, \mathrm{Cu}$, As) carried out on 37 blocks made it possible to understand that there is a correlation between these elements. But, the mineralurgical tests were carried out on 28 blocks. The last step is to make the interpretation of the elements that influence on the recovery of gold in yalea deposit.

\subsection{Studies of the Elements Who Influence on the Recovery of Gold during of Mineral Treatment}

Analysis of Block Models: Cu, As, Au

These models are based on core drilling data from the area (Figure 2).

After the survey, the cores are sampled and sent to the laboratory for phased analysis $(\mathrm{Au}, \mathrm{Cu}, \mathrm{As})$. The results of this analysis are treated with the Vulcan/GemCom software, which allows us to have these models (Figure 3). These models are updated as we have data from survey (Figure 4).

1) Gold model block:

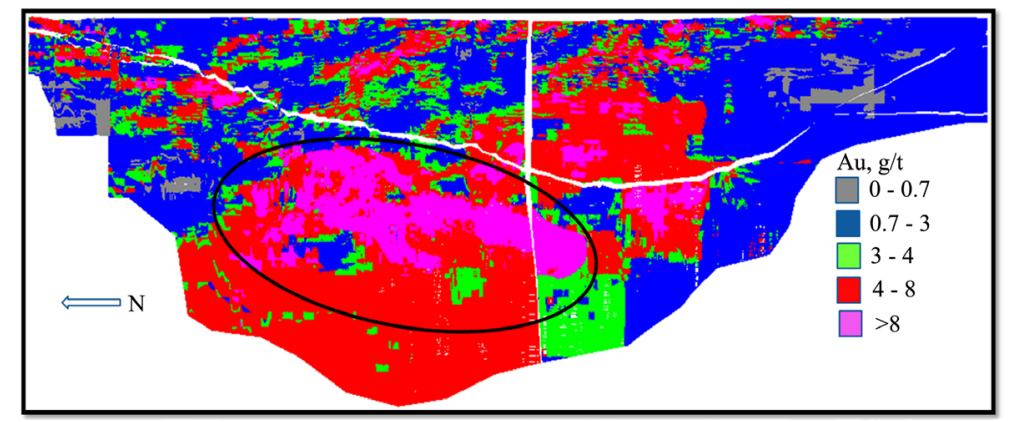

Figure 2. The gold model block.

2) Copper model block:

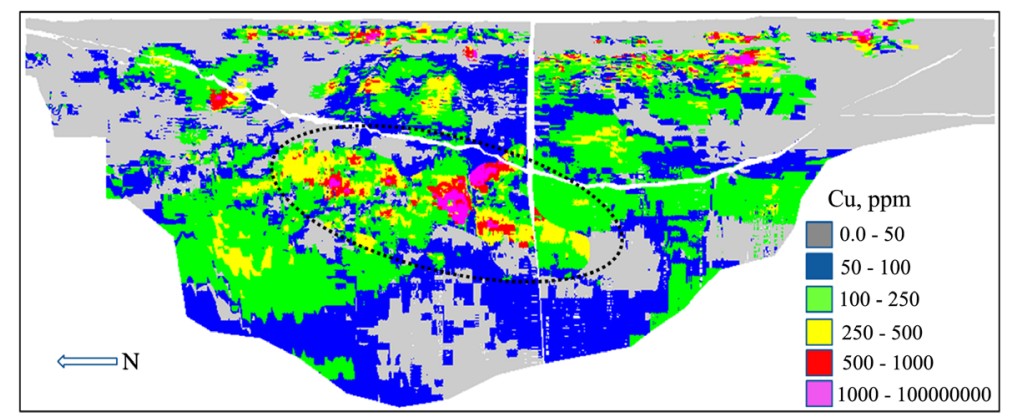

Figure 3. Copper model block. 
3) Model block of Arsenic:
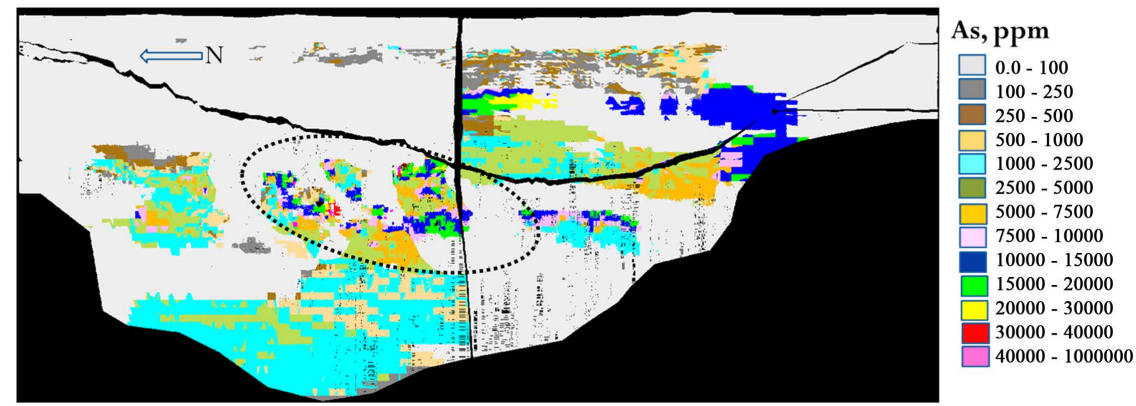

Figure 4. The model block of Arsenic.

The analysis of these three block models shows a high gold, copper and arsenic content center of the deposit. To verify the link between these three elements in the deposit, 37 blocksextracts from the deposit are sampled and sent to the laboratory for analysis multielement $(\mathrm{Au}, \mathrm{Cu}, \mathrm{As})$ due to two $\left(\mathrm{O}_{2}\right)$ samples of 50 kg per block.

\subsection{Multielement Analysis (Au, Cu, As) of Block Samples Laboratory}

Statistically from the results of these 37 blocks, these two graphs show that there are a correlation between gold and arsenic on the one hand and on the other hand between gold and copper and (Or-Arsenic) vary in the same direction. But gold is more related to Arsenic $(\mathrm{R}=0.7)$ than to copper $(\mathrm{R}=0.6)$. This is due to the fact that Gold is in inclusion of Arsenopyrite II, but it is often found in association with chalcopyrite and/or Tennantite in fractures of pyrites II (Figure 5) and (Figure 6).

The average content of Arsenic in the blocks is higher (14,337 ppm) than the average copper (229 ppm), this is due to the fact that arsenopyrite is one of the dominant sulphides (35\% of sulphides), chalcopyrite and Tennantite (5\% of sulphides) are sulphides miners in the deposit. The average gold content in the blocks is $6 \mathrm{~g} / \mathrm{t}$.

These three (03) elements show almost the same signature, which confirms that Copper and Arsenic are tracer elements of Gold in the Yalea deposit (Figure 7).

\subsection{Influence of Copper and Arsenic on Gold Recovery}

It can be seen that the curve increases gradually with $\log (\mathrm{Cu})$ up to 2.06 . From there, it shows a plateau between 2.06 and 2.16 and beyond 2.16 it decreases (Figure 8).

- $\log (\mathrm{Cu})=2.06$ is the threshold content, content beyond which the recovery no longer increases.

- The plateau between $\log (\mathrm{Cu})=2.06$ and $\log (\mathrm{Cu})=2.16$ shows that the recovery is stationary in this interval. 


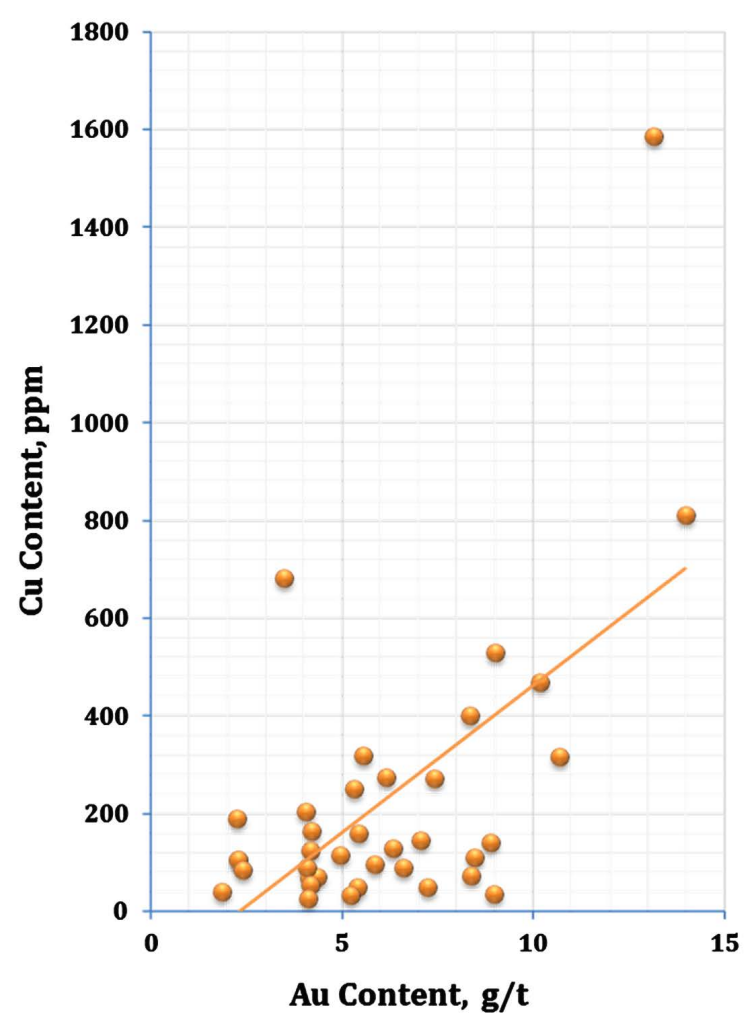

Figure 5. Relationship between $\mathrm{Cu}$ content and $\mathrm{Au}$ content in blocks.

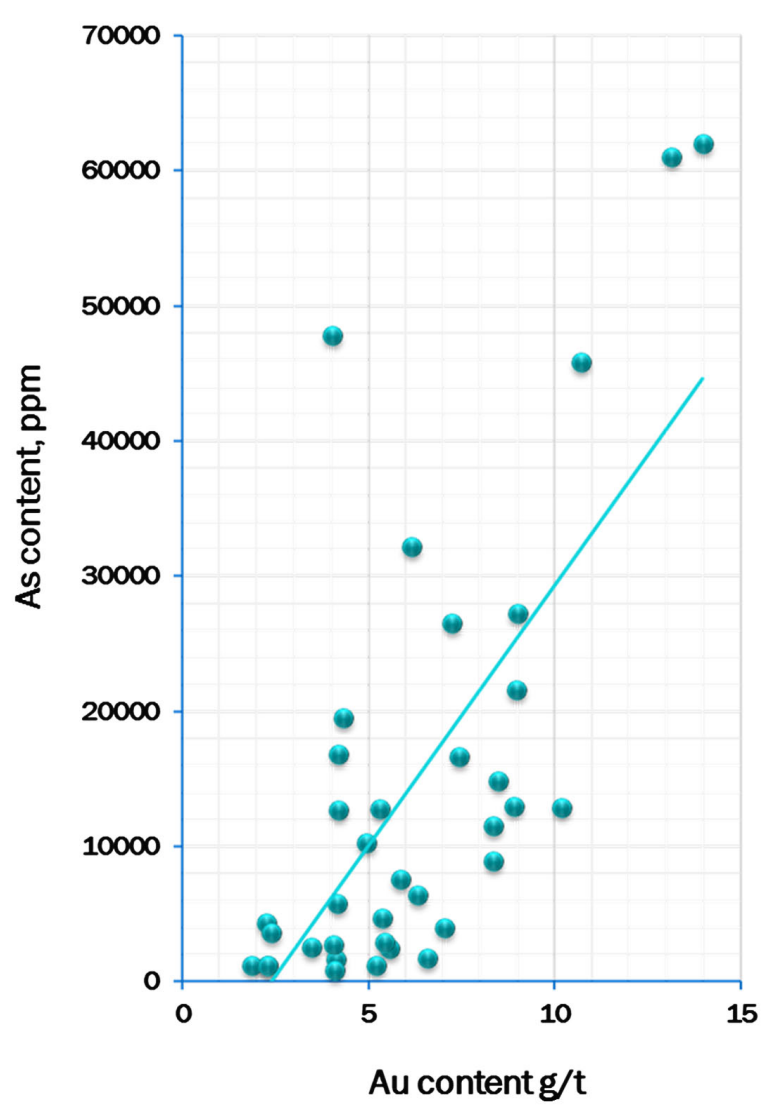

Figure 6. Relationship between As content and Au content in blocks. 


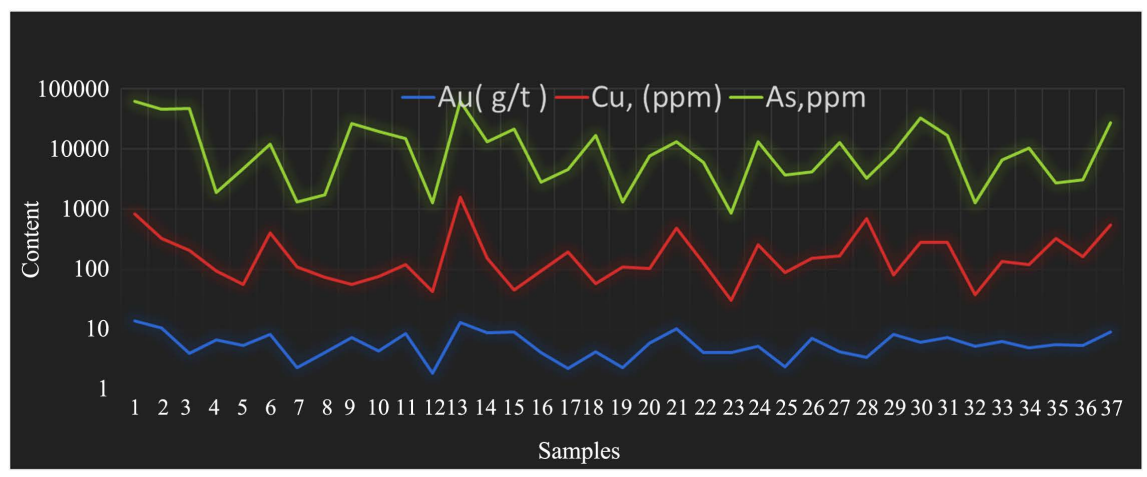

Figure 7. Curves of variation of the contents in the blocks.

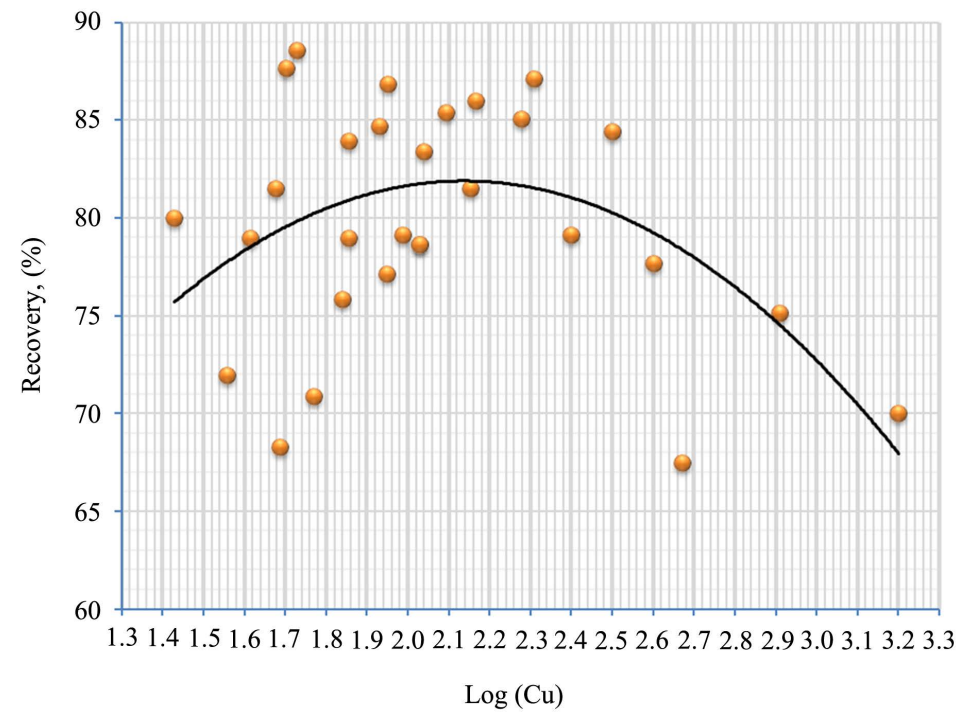

Figure 8. Recovery of gold as a function of $\log (\mathrm{Cu})$.

- Beyond $\log (\mathrm{Cu})=2.16$, the recovery drops.

$\log (\mathrm{Cu})=2.06$ and $\log (\mathrm{Cu})=2.16$ (on the graph) lie between $\log (\mathrm{Cu})=$ 2.04 and $\log (\mathrm{Cu})=2.17$, these correspond to $110 \mathrm{ppm}$ and $146 \mathrm{ppm}$ of copper.

It is found that as well as copper recovery increases with $\log$ (As) up to 3.6 which corresponds to the threshold content of Arsenic (3990 ppm) (Figure 9). After the curve becomes almost stationary between the $\log ($ As) $=3.6$ and $\log$ $($ As $)=3.7$. Beyond $\log ($ As $)=3.7$ which corresponds at $4710 \mathrm{ppm}$ Arsenic, recovery falls with increasing Arsenic content.

So in this interval (3990 ppm to $4710 \mathrm{ppm}$ ), the recovery does not vary with the content Arsenic.

The linear regression line $(\mathrm{R}=0.5)$ is decreasing, which shows that the higher the content in gold increases, the more the recovery decreases. This can be explained by graphs 3 and 4 (variation of the gold content according to that of arsenic and that of copper) which shows that the gold content increases with the content of copper and that of arsenic in the blocks. We have good recoveries between 4 and $7 \mathrm{~g} / \mathrm{t}$ of gold (Figure 10).

According to the consumption of Cyanide, we can see that, the good recove- 
ries are between 450 to $570 \mathrm{~g} / \mathrm{t} \mathrm{NaCN}$. The correlation coefficient is $\mathrm{R}=0.4$ (Figure 11).

It can be seen that the curve increases up to the point $\mathrm{Cu}=200 \mathrm{ppm}$ and $\mathrm{H}_{2} \mathrm{O}_{2}$ $=31$ ppm: the copper gradually consumes Oxygen. From this point to the point $\mathrm{Cu}=200 \mathrm{ppm}$ and $\mathrm{H}_{2} \mathrm{O}_{2}=39$ ppm the curve becomes almost stationary, which implies that the copper has not consumed Oxygen in this interval.

This interval corresponds to the saturation interval of copper. Beyond this interval the curve increases, this shows a consumption of Oxygen by the Copper. So for a copper content of $200 \mathrm{ppm}$, it is saturated with $31 \mathrm{ppm}$ of $\mathrm{H}_{2} \mathrm{O}_{2}$ (Figure 12).

This graph shows that there is a very high correlation $(\mathrm{R}=0.70)$ between the content of Arsenic in ore and $\mathrm{H}_{2} \mathrm{O}_{2}$ consumption during pre-oxygenation.

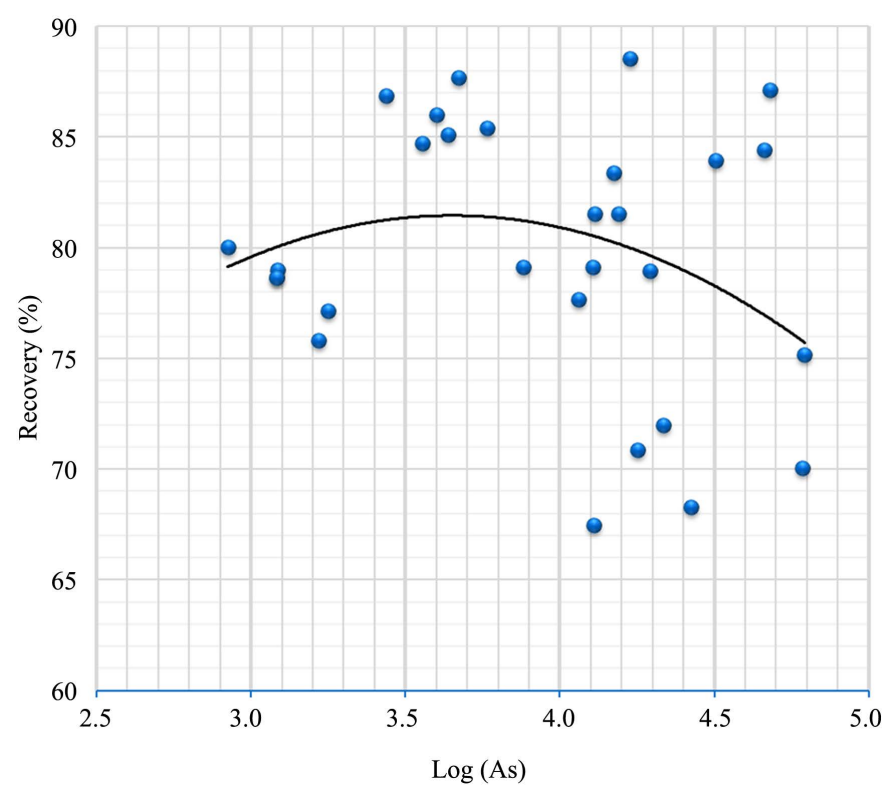

Figure 9. Gold Recovery vs. Log (As).

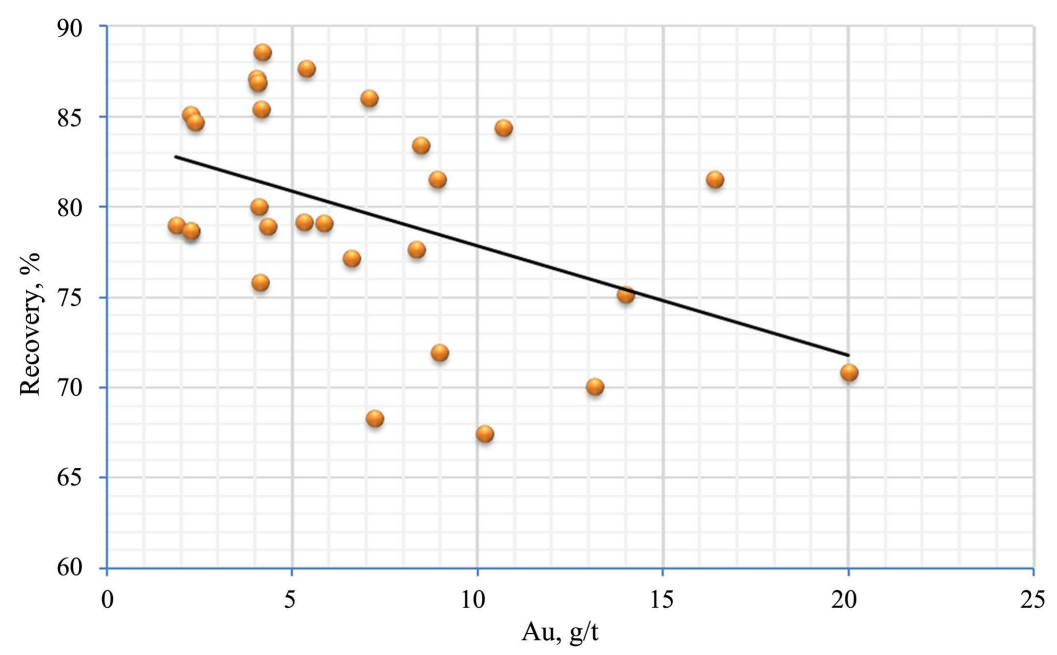

Figure 10. Gold recovery rate as a function of gold content in the ore. 


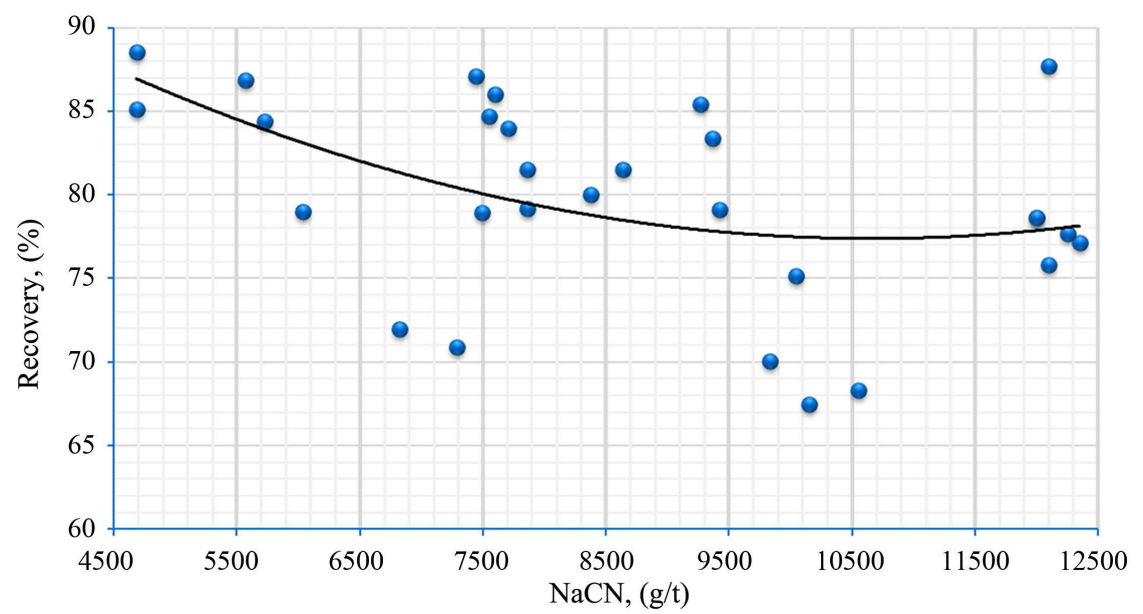

Figure 11. Recovery of gold according to the consumption of cyanide.

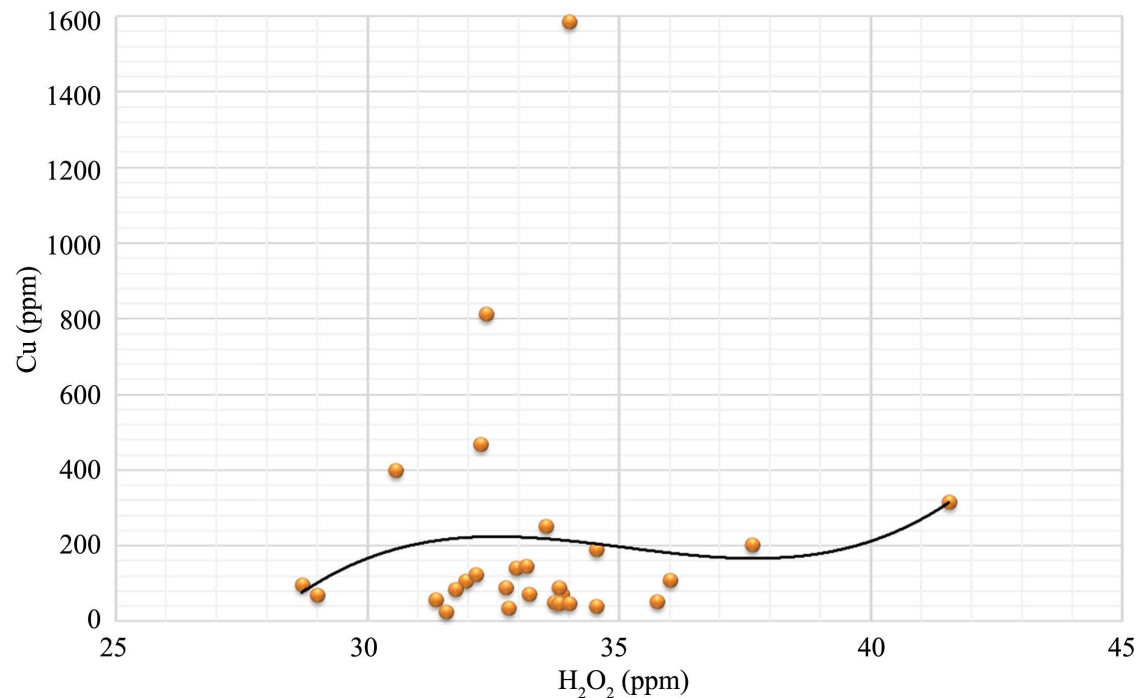

Figure 12. $\mathrm{H}_{2} \mathrm{O}_{2}$ consumption as a function of copper content.

An interpolation of the trend curve shows us a plateau at $5000 \mathrm{ppm}$ of Arsenic, corresponds to the saturation range of Arsenic at $29 \mathrm{ppm}$ of $\mathrm{H}_{2} \mathrm{O}_{2}$.

Beyond this content the curve rises considerably. The higher the content of Arsenic in the blocks, the more oxygen it takes mitigate it. So Arsenic is a consumer of Oxygen (Figure 13).

Among the elements consuming oxygen, do not forget the Iron, it oxidizes very easily. This graph shows that it consumes oxygen. It reaches saturation at 30 ppm $\mathrm{H}_{2} \mathrm{O}_{2}$ when its amount in the ore reaches $8 \%$. Beyond $8 \%$ it starts again consumption (Figure 14).

\section{Results and Discussion}

In the Yalea deposit the higher the gold content in the blocks, the higher the content of the increased copper and arsenic, which could have a considerable impact on the gold recovery in blocks of high gold content. 
In ore, the higher the gold content, the higher the copper and arsenic contents in the blocks increase, the more the recovery decreases.

The Arsenic content is higher than the copper content in the samples, but the graphs show that recovery is more related to copper grades than to arsenic. Since the correlation coefficient between copper and recovery is higher $(R=0.5)$ than that of arsenic with recovery $(\mathrm{R}=0.3)$.

According to these figures, Arsenic is the most oxygen intensive element among these elements ( $\mathrm{As}, \mathrm{Cu}, \mathrm{Fe}$ ), since the correlation coefficient between its content in the blocks and the consumption of $\mathrm{H}_{2} \mathrm{O}_{2}$ is the highest $(\mathrm{R}=0.70)$. After it is the Iron $(\mathrm{R}=0.25)$ then the Copper $(\mathrm{R}=0.13)$.

We see that the average feed content is $6 \mathrm{~g} / \mathrm{t}$ with a recovery of $85 \%$ (Table 3 ).

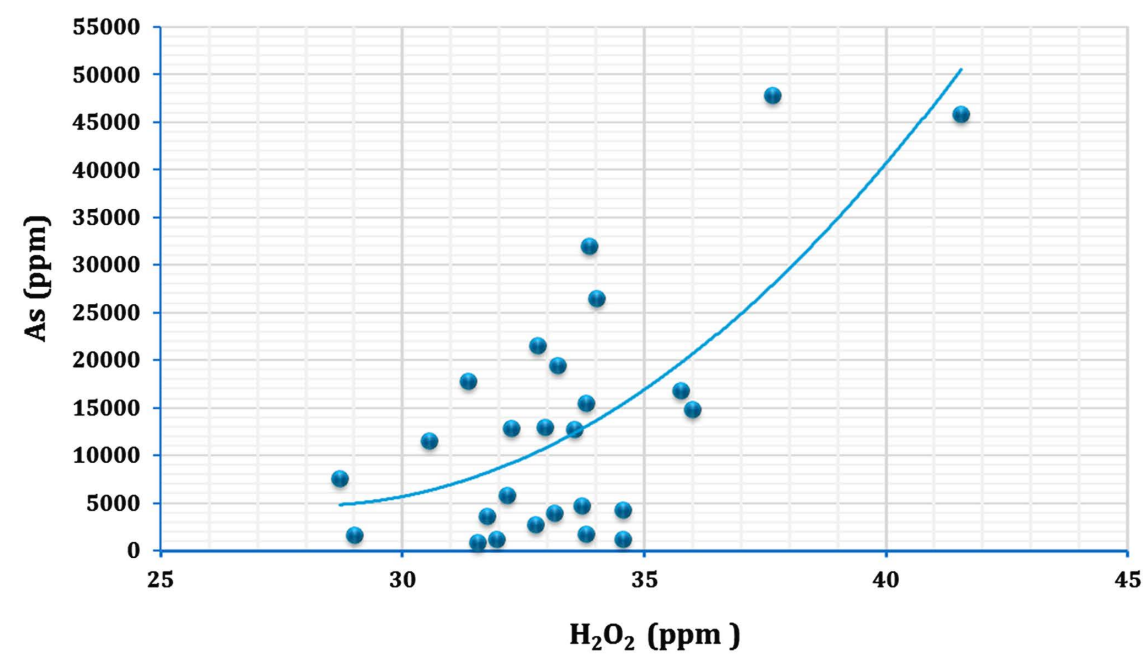

Figure 13. $\mathrm{H}_{2} \mathrm{O}_{2}$ consumption as a function of Arsenic content.

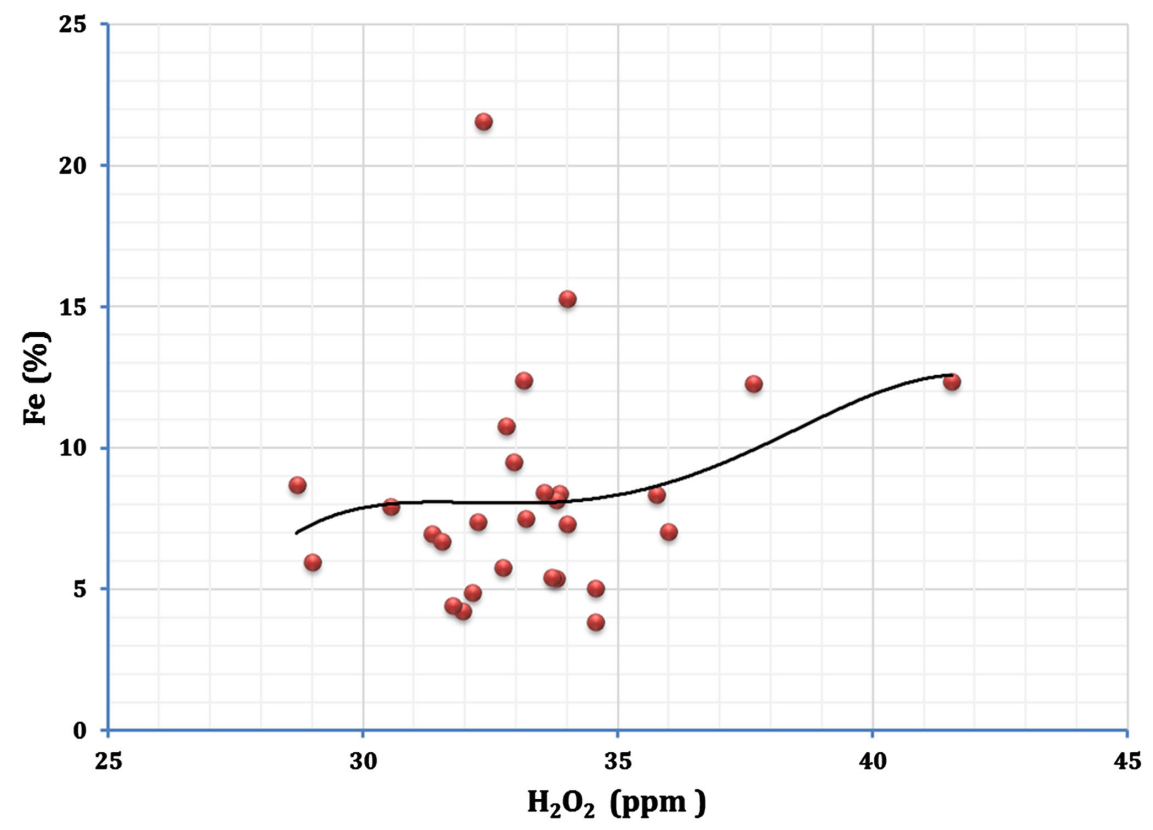

Figure 14. $\mathrm{H}_{2} \mathrm{O}_{2}$ consumption as a function of the amount of iron. 
Table 3. Comparison between yalea deposit and other deposit.

\begin{tabular}{cccccc}
\hline Deposits & $\mathrm{Au} \mathrm{(g/t)}$ & $\mathrm{Rec}(\%)$ & $\mathrm{NaCN}(\mathrm{g} / \mathrm{t})$ & $\mathrm{Cu}(\mathrm{ppm})$ & $\mathrm{As}(\mathrm{ppm})$ \\
\hline Gara & 4.8 & 96 & 620 & 22 & 10,040 \\
Gounkoto & 5.6 & 91 & 660 & 63 & 111 \\
Yalea OPP & 5.3 & 72 & 890 & 180 & 21,750 \\
YaleaUG & 8.0 & 80 & 850 & 594 & 24,587 \\
Content average & 6 & 84 & 755 & 215 & 14,122 \\
\hline
\end{tabular}

This recovery is low due to the fact that the recovery of Yalea OPP is very critical $72 \%$ [10]. The interaction of hydrothermal fluids with metamorphosed carbonaceous matter (CM) could be one of the causes of the reduction of hydrothermal fluids and formation of the respective mineralization [11]. However Alamoutala gold deposit is part of the Yatela gold district, which is located in the Kédougou-Kénieba inlier (KKI), a window of deformed Birimian rocks (Paleoproterozoic, ca. 2200 - $2050 \mathrm{Ma}$ ) that outcrop in eastern Senegal and western Mali [12].

But in the Loulo-Gounkoto complex in the Kédougou-Kéniéba Inlier hosts three multi-million ounce orogenic gold deposits, situated along the Senegal-Mali Shear Zone [13]. It is the ore that consumes the most cyanide due to its mineralogical composition.

Containing secondary sulphides: covellite $(\mathrm{CuS})$ and chalcocite $\left(\mathrm{Cu}_{2} \mathrm{~S}\right)$ which generate ions $\mathrm{Cu}^{+}$and $\mathrm{Cu}^{2+}$ which are very active with cyanide is the reason why it consumed more cyanide than Yalea UG ore that contains a relatively greater amount of copper high. The latter contains chalcopyrites which give $\mathrm{Cu}^{3+}$ ions less active than $\mathrm{Cu}^{+}$and $\mathrm{Cu}^{2+}$. In this case, it is necessary to have a thorough pre-oxygenation and a cyanidation procedure; the one that does will not be more economical.

\section{Conclusions}

In this paper, Copper and Arsenic are tracer elements of Gold in the Yalea deposit, which is directly observable on block models (high concentrations of gold correspond to the high concentrations of copper and arsenic).

The interpretation of the results of the mineralogical tests carried out on the 29 blocks showed that gold recovery from Yalea ore is a function of the grade of copper and Arsenic in the ore, as well as the dosage of Cyanide.

The oxidized ore of Yalea has a considerable influence on the recovery rate of gold, due to the presence of secondary sulphides (covellite and chalcocite).

Arsenic is more related to gold $(\mathrm{R}=0.5)$ than copper $(\mathrm{R}=0.2)$, and its content is higher than that of copper in the blocks. But recovery is more related to grades copper $(R=0.5)$ in the ores than at the Arsenic contents $(R=0.3)$.

In conclusion, copper and Arsenic are elements that have a considerable influence on the gold recovery in the Yalea deposit. 


\section{Acknowledgements}

The Minister of Mines of Mali has financially supported this study research under (SYSMIN PROJECT 2002), which we would like to thank sincerely.

Special thanks to my supervisor in state key laboratory of geological processes and mineral resources, China University of Geosciences, Wuhan. Thanks also all colleagues from the University of Segou for their advice.

\section{Conflicts of Interest}

The authors declare no conflicts of interest regarding the publication of this paper.

\section{References}

[1] Mainguy, C. (2010) Natural Resources and Development: The Gold Sector in Mali. Resources Policy, 36, 123-131. https://doi.org/10.1016/j.resourpol.2010.10.001

[2] Teschner, B.A. (2011) “Orpaillage Pays for Everything”: How Artisanal Mining Supported Rural Institutions Following Mali's coup d'etat. Futures, 62, 140-150. https://doi.org/10.1016/j.futures.2014.04.016

[3] Feybesse (2006) Geological Synthesis of the Malian Birimian Edition Sysmin. Unpublished Report.

[4] Hilson, G. (2012) Family Hardship and Cultural Values: Child Labor in Malian Small-Scale Gold Mining Communities. World Development, 40, 1663-1674. https://doi.org/10.1016/j.worlddev.2012.03.017

[5] IbrahimaBallo, K.A.A.H., Guindo, B., Sanogo, L., Ouologuem, Y., Daou, G. and Traore, A. (2015) The Syama and TabakoroniGoldfiefd, Mali. Ore Geology reviews, 78, 578-585. https://doi.org/10.1016/j.oregeorev.2015.10.019

[6] Masurel, Q., Thébaud, N., Mille, J., Ulrich, S., Hein, K.A.A., Hanssen, E., Kaisin, J. and Tessougue, S. (2015) The Yatela Gold Deposit in Mali, West Africa the FinalProduct of Long-Lived History of Hydrothermal Alteration and Weathering. Journal of African Earth Sciences, 113, 73-87.

[7] Traoré, Y.D., Siebenaller, L., Salvi, S., Béziat, D. and Bouaré, M.L. (2015) Progressive Gold Mineralization along the Syama Corridor, Southern Mali (West Africa). Ore Geology Reviews, 78, 586-598. https://doi.org/10.1016/j.oregeorev.2015.11.003

[8] Beziat, D., Dubois, M., Debat, P., Nikiema, S., Salvi, S. and Tollon, F. (2008) Gold Metallogeny in the BirimianCraton of Burkina Faso (West Africa). Journal of African Earth Sciences, 50, 215-233. https://doi.org/10.1016/j.jafrearsci.2007.09.017

[9] Bassot, J.P, Meloux, J. and Traore, H. (1981) Géologie du Mali. Unpublished Report.

[10] Hammond, N.Q., Robb, L., Foya, S. and Ishiyama, D. (2011) Mineralogical, Fluid Inclusion and Stable Isotope Characteristics of BirimianOrogenic Gold Mineralization at the Morila Mine, Mali, West Africa. Ore Geology Reviews, 39, 218-229. https://doi.org/10.1016/j.oregeorev.2011.03.002

[11] Lambert-Smith, J.S., Lawrence, D.M., Vargas, C.A., Boyce, A.J., Treloar, P.J. and Herbert, S. (2015) The Gounkoto Au deposit, West Africa: Constraints on Ore Genesis and Volatile Sources from Petrological, Fluid Inclusion and Stable Isotope Data. Ore Geology Reviews, 78, 606-622.

https://doi.org/10.1016/j.oregeorev.2015.10.025 
[12] Kríbek, B., et al. (2015) The Origin and Hydrothermal Mobilization of Carbonaceous Matter Associated with Paleoproterozoic Orogenic-Type Gold Deposits of West Africa. Precambrian Research, 270, 300-317.

https://doi.org/10.1016/j.precamres.2015.09.017

[13] Rehren, Th. and Nixon, S. (2014) Refining Gold with Glass-An Early Islamic Technology at Tadmekka, Mali. Journal of Archaeological Science, 49, 33-41.

https://doi.org/10.1016/j.jas.2014.04.013 